\title{
Image Construction of Islamic Defenders Front in the Jakarta Post Online News
}

\author{
Siti Nurul Hidayah \\ State University of Jakarta, Indonesia \\ Email: nurulhidayah467@gmail.com
}

\begin{abstract}
This study aimed to observe image construction of the Islamic Defenders Front (FPI) based on six articles of the Jakarta Post Online News about the FPI's protest toward three issues: Ahmadiyah, the arrival of Lady Gaga in Indonesia, and Ahok as the substitute governor of Jakarta. The author qualitatively explored the FPI's image using Halliday's systemic functional linguistics (SFL), which defines the types of process in a clause. The author also analyzed the thematic structure of the clause to support the analysis of each type of process. The result was approximately 208 clauses from the six news articles. This study shows that the dominant process in the abovementioned three issues is the material process. The material process represents $51 \%$ in the issue of Ahmadiyah, $41 \%$ in the issue of the arrival of Lady Gaga, and $70 \%$ in the issue of Ahok as Jakarta's substitute governor. This material process shows that the Jakarta Post Online News constructed a negative image of the FPI's by reporting this organization's action during the protest. In the issue of Ahmadiyah, the FPI was framed as anarchist, while in the issue of Ahok and of Lady Gaga it was represented as protestor. The analysis of thematic structures shows the FPI as the dominant topical theme, which indicates the FPI was the main topic of the articles.
\end{abstract}

Keywords: news article; Systemic Functional Linguistics; image construction of the FPI; thematic structure; types of process

\section{INTRODUCTION}

Since when the Indonesian government applied the reformation, in the middle of 1998, the wriggle of media has developed. The deliberacy of mass media has supported journalists to argue and share their idea. This development is hardly tied with the regulation and the improvement of the government's politics. The improvement of the government system has created euphoria in mass media, especially to some power possessor.

Mass media are a cultural industry that produces and distributes songs, novels, newspapers, and other cultural products to a large number of people (Campbell, 2012). In shaping culture, mass media use many strategies with reinforcing images and representation of something. Mass media play a role not only as the source of information, but also as the stick holder of shaping culture and democracy (Campbell, 2005). Thus, they can be a vehicle to influence public opinion and raise awareness towards issues. Moreover, this influence can shape the audience's mindset towards some cases.

Newspapers are still considered as the best mass media in delivering news. Beside news, they can be used as the source of daily activities; newspapers give the readers both information and entertainment. They also help the readers to make a choice, such as the preference of food or leaders to elect (Campbell, 2012, p. 221). Newspapers are of two kinds: Ordinary printed daily news and its online version.

Terrorism has high value in the news in Indonesia, hence the perpetrators use religion to legitimate their acts. As a country which consists of $85.2 \%$ of Muslims, 
Indonesia is frequently faced with the issue of terrorism. One of the organizations which is embodied terrorism by the mass is the Islamic Defenders Front (FPI). Their motto is "live honorably or die as a martyr," so they represent themselves as the ally of the government security to control sin and vice (Woodward et al., 2012). They are a controversial organization which always does some actions towards issues in Indonesia. The issues on which they mostly focus are morality and Islam, as in the case of the issue of Ahmadiyah, the arrival of Lady Gaga, and Ahok as the Jakarta's governor. These are examples of the kind of issues with which they concern. The case of Ahmadiyah is an example of Islamic issue. Indeed, as one of the heretical versions of Islam, Ahmadiyah has been attacked by the FPI's members who follow the Qur'anic edict Amar Ma'ruf Nahi Munkar. The second case (i.e., Lady Gaga) is an example of moral issue, As the FPI pays full attention to Indonesian youth's moral. The last case (i.e., Ahok as Jakarta's governor) is an example of the FPI's awareness of the government's politics.

As one of the roles of media is reinforcing the representation of something, the usage of language implies important rules. Media use a certain language to represent social issues or social actors. From mass media, people know how a social issue is represented (Campbell, 2005). As a result, in this research, the author aimed to dig up how the Jakarta Post, as one of the English daily newspapers in Indonesia, constructs the image of the FPI through its articles while delivering the news. The Jakarta Post.com, as the online version of the newspaper, provides not only breaking news, but also updates and accurate news and analysis. It aspires to be the top Indonesian reference that will serve both local and international readers.

This research deals with Halliday's systemic functional linguistics (SFL). SFL is an approach to text analysis because it allows to explore the relationship between language and aspects of social life (Haratyan, 2011). By using this approach, the author investigated how the Jakarta Post represents the FPI against the chosen issues, through the language this newspaper uses. The language the media use might connote some different meanings. Thus, the different meanings must be conveyed thoroughly.

SFL encompasses a metafunction regarding the basic function of language which relates to people's experience in social life (Halliday \& Matthiessen, 2004). This metafunction is divided into three categories: Ideational, interpersonal, and textual (Halliday \& Matthiessen, 2004). These three categories of the metafunction are realized through the grammar of a language (Halliday \& Matthiessen, 2004). The ideational metafunction constructs a model of experience and corresponding status in clause as representation. A clause as representation has an important part, namely the transitivity system, which contributes the classification of the process, participants, and circumstances used in text (Halliday \& Matthiessen, 2004). Transitivity structures show the representational meaning of a clause (Halliday $\&$ Matthiessen, 2004). Besides, the textual metafunction (i.e., clause as message) is also an important part which provides the theme structure of a clause. The theme structure shows the organization of the message. In addition, this structure includes the clause related to the discourse and the context of the situation which is being produced. The last metafunction is interpersonal (i.e., language as exchange). This feature represents people's mood while interacting with the social environment (i.e., declarative, imperative, and interrogative). The author used these elements to describe how the Jakarta Post Online News depicts the FPI. However, the author only focused on the ideational metafunction.

The ideational metafunction provides grammatical resources at the inner and outer experience as the function and meanings of the world through the transitivity system (Haratyan, 2011). Thus, this metafunction implies that the meaning is constructed in a clause which includes the process, participants, and circumstance as the main parts of meaning construction. According to Halliday and Matthiessen (2004), there are six types of process: Material, mental, relational, behavioral, verbal, and existential.

The material process consists in doing and happening. It shows some particular events which are carried out by an individual and which take place in some particular settings. The actor is the participant subject who brings the change. The other element is the "goale or "range," which is the process extended.

The mental process consists in sensing and feeling, and is concerned with human consciousness. It is classified into three categories: Emotion, cognition, and perception. The "senser" is the human participant and the "phenomenon" is what the senser perceives.

The relational process consists in being and having. It is the process of characterizing and identifying. Halliday and Matthiessen (2004) defined three main types of relation, namely Intensive, possessive, and circumstantial, and that each of them comes into two modes, namely attributive and identifying. The participants involved in this process are the carrier and the attribute.

The behavioral process concerns physiological and psychological behavior (e.g., breathing, coughing, 
smiling, dreaming, and staring). The behaver is the main participant in this process, as the actor or sensor in the material and mental processes, respectively. In the behavioral process, the common typical pattern only consists of the behaver and the process itself.

The verbal process consists in saying. The participant is the speaker as "sayer," and the "target" represents the addressee. In a verbal clause, the process is realized by a verbal group and the common verb (e.g., say, told, and talk).

The existential process represents something which exists or happens (Halliday \& and Matthiessen, 2004). It is characterized by the word "there" and the verb "to be," which indicate the feature of existence. The circumstantial part of this process contains time or place. The event that exists is labeled as "existent" and is construed as a thing person, object, institution, action or event.

Woodward et al. (2012) conducted a similar research of this field. In their work, they focused on the hate speech that the FPI used while doing their mission. They also carried out some research on the translation of the banner outside the FPI's Jakarta Headquarters, and investigated the syntax to reveal the hate speech of the Indonesian FPI. They concluded that the FPI is one of the domestic Indonesian terrorist organizations. Instead, in this research, the author focused on Jakarta Post's image construction of the FPI in its articles on specific issues. Besides, the author used Halliday's SFL for her analysis. Thus, this study not only focuses on the FPI's hate speech, but pays attention also to the action showing this organization's awareness of morality and Islam issue in Indonesia.

\section{FINDINGS AND DISCUSSION}

The author compiled this study through the analysis of the clauses of the articles using Halliday's SFL theory. The analysis involved the use of the ideational metafunction of the theory. The image of the FPI is constructed negatively through the material process. The author described the FPI's action towards three chosen issues: Ahmadiyah, the arrival of Lady Gaga, and Ahok as Jakarta's governor. The material process represents $51 \%$ in the case of Ahmadiyah, $41 \%$ in the case of the arrival of Lady Gaga, and $70 \%$ in the case of Ahok as the Jakarta's governor.

\section{Image Construction of the Islamic Defenders Front in the Case of Ahmadiyah}

This case arose in 2012. In this study, the author picked two articles from the Jakarta Post regarding the
Ahmadiyah. The researcher identified 92 clauses and analyze their processes.

Figure 1 shows that the material process takes the first rank. The image of the FPI is constructed through their action towards Ahmadiyah, which is considered as one of the heretical versions of Islam using the material process. The material process is supported by the verbal process, which means that the action of the FPI is followed by the participant and the victims' testimony. The image construction can be seen in some processes, such as mobbed, dressed and vandalized, attacked, and starting throwing: "Dozens of Islam Defenders Front youth mobbed an Ahmadiyah secretariat office and mosque in Makassar, South Sulawesi, on Saturday" (JP.1/ Clause No.1)

The process "mobbed" shows that the FPI was one of the hardline organizations of Islam that did such action to do some protest. The journalists intentionally chose the verb "mob" instead of "visit" to describe the condition of the day, which was full of crowd and anger and could drive to violence. The FPI was described as the actor who caused the riot through its mob. In this case, the FPI did "mob" to express its anger towards Ahmadiyah which the FPI considered as a heretical version of Islam.

The FPI's identity was then better conveyed in the following processes:

The angry youths, dressed in FPI style, with white robes and hats, then vandalized a plaque at the office and the walls of the Ahmadiyah mosque on Anuang Street. They also burned a poster of Mirza Ghulam Ahmad, who Ahmadis consider their prophet (JP1/Clause No.10).

These sentences consist of two clauses. The first clause has two material processes and one clear participant, namely "the angry youths," which referred to the youth of the FPI. These two clauses detailed the participants. Their appearance (i.e., well dressed, in white robes and hats) symbolized Muslim outfits. The verb "dressed in" was used instead of "wear" to reveal the meaning of wearing a

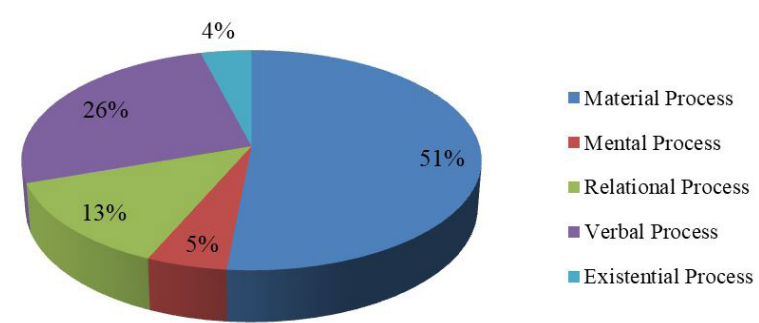

Figure 1. Percentage of type of process in the case of Ahmadiyah 
particular type of clothes: The clothes of Muslims. Their brutal activities vandalizing Ahmadiyah's property (i.e., a plaque at the office and walls intentionally) becomes the antithesis of Muslim character. The journalist used the word "vandalize" instead of "warn" to show their criminal attitudes with the physical attack. The journalist put these two antitheses in one sentence, in order to strengthen the negative image of the FPI. Their outfit was Muslim; however, their character is not Muslim.

Moreover, the second sentence added information about their burning the poster of Ahmadi's people. Beside vandalizing the plaque, they also burned the image of who they considered as Ahmadiyah's prophet. In the first article, beside construction the FPI as the main actor of the material process, the journalist was also taking police's and Ahmadi's attitude. The police as the symbol of government shaped as doing their job desk appropriately: "The police, led by South Sulawesi Police chief Insp. Gen. Johny Wainal Usman, attempted to evacuate the Ahmadis from the mosque, located adjacent to the secretariat office" (JP1/ Clause No. 22).

The journalist used the verb "evacuate" rather than "move" to show that the mosque was dangerous and it was necessary to move the Ahmadis to a safer one. Thus, the one who evacuates is the police, while the Ahmadis is the victim, and the FPI implicitly said that the Ahmadis had to be evacuated because of the FPI's attack.

This material process was then supported with the verbal process, that is the direct speech which emerged from the Ahmadis. It was reported that they were innocent: "We will stay here because this is our home. We do not have any problem with the FPI or any other groups. We are not afraid' he said".

This quotation came from Jamaluddin's secretariat as caretaker of Ahmadiyah. They were explained not having any problems with everyone or groups, so they implicitly said that the FPI was wrong in attacking them. The next article supported this image; it began with the report of the FPI's attack on Ahmadiyah in another place: "Hundreds of people attacked an Ahmadiyah mosque in Babakan Sindang village, Tasikmalaya, West Java, prior to a Friday prayer" (JP2/Clause No. 1).

This second article of the case of Ahmadiyah began similarly to the first one. The journalist directly informed the readers from the first sentence with the material process "attacked." The process "mobbed and attacked" are two activities which were obviously executed by some criminal agents. The journalist used the verb "attacked" instead of "mobbed" to explain doing the aggression with the intention of hurting the rivals and defeat them. Moreover, the journalist did not mention the actor clearly; "hundreds of people" can be interpreted as one hundred, two hundred, and so on. Consequently, "hundreds" is intentionally used to drive the reader's conception about the FPI's troops: "'They initially shouted. But they started throwing stones at windows a few minutes later and broke into the mosque,' Enda told The Jakarta Post on Friday" (JP2/Clause No. 4).

This clause is actually a verbal process which involved the victim (i.e., Endah) to strengthen the journalist's idea shaping the reader's opinion about the FPI. Endah is a witness from Ahmadis who retells the FPI's action. They are the ones who wore the Muslim attribute (i.e., white robes and hats), shouted, threw the stones at the windows, and finally broke into the mosque; this means doing such criminal brutal activities.

The material process above allows to conclude that the journalist constructed a negative image of the FPI through its action against Ahmadiyah, that is one of the heretical versions of Islam. The journalist used the material process which revealed the physical attack. The journalist attributed the actions of mobbing, attacking, burning, shouting, and other rush activities to the FPI.

\section{Image Construction of the Islamic Defenders Front in the Case of the Arrival of Lady Gaga}

The arrival of Lady Gaga in Indonesia had stimulated the FPI to confess their anger. This case arose in the middle of 2012. The relevant two articles consist of 65 clauses, which the author intentionally analyzed using Halliday's SFL theory. The analysis provided details about the process, participant, and circumstances which would drive the reader's opinion about the FPI.

In the second case, namely the arrival of Lady Gaga, the FPI was still reported as one of the organizations which frequently protested against some issues. This

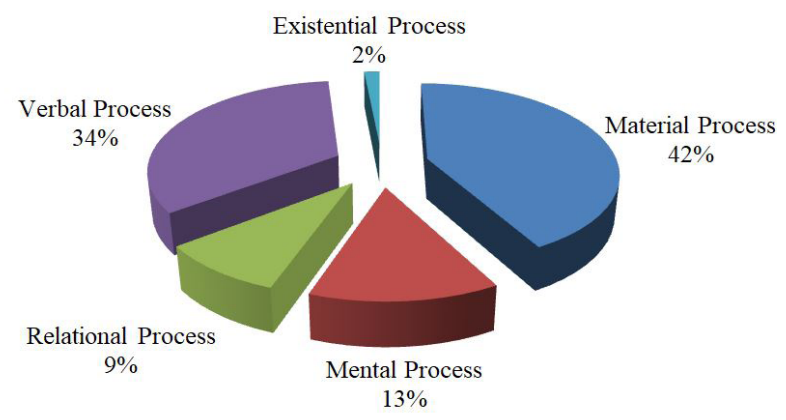

Figure 2. Percentage of type of process in the case of the arrival of Lady Gaga 
material process was also followed by the verbal process. In this part, the difference between material and verbal process is only of approximately $10 \%$. The journalist tried to convey his/her objectivity in delivering the news by quoting many testimonies from the pro and contra sides. The image of the FPI can be seen in some processes, such as say and refuse. "If you want chaos in Jakarta, just continue to hold the concert.' He said" (JP.3/Clause No.8). This first clause is a verbal process which came from the chairman of FPI, Habib Rizieq. This warning was hard and voice activated system within their network, most people in Jakarta know how they take to the streets doing protest. This testimony from the chairman really worked to reveal their attitude for not permitting the concert.

The next article had three main participants: The Jakarta Police, the FPI, and the promoter. These three participants were joined together to reveal the three sides of canceling the concert: "The Jakarta Police say they will not issue a recommendation to the National Police to issue a permit for Lady Gaga's concert on June 3 at Bung Karno Stadium in Senayan, Central Jakarta" (JP.4/ Clause No.1).

This sentence revealed the attitude of the Jakarta Police who implicitly supported the FPI. This verbal process is needed to reassure the readers. It was not a direct sentence, but the meaning was sufficient to show their agreement. This agreement was supported by the reasons which reported it was not suitable for local audience to let Lady Gaga run the concert. "'We refuse to have Gaga step on our land. She's bringing the faith of Satan to our country and thus will destroy the nation's morals,' the chief of FPI's Jakarta branch, Habib Salim Alatas, said" (JP.4/Clause No.21).

This sentence consisted of two processes, namely the main process "said" and its quote. This sentence explained the FPI's ideology through its leader about Lady Gaga using a testimony rather than paraphrasing his statement freely. Habib Salim Alatas, as one of the elite officials of the FPI, stated that they will refuse firmly the arrival of Lady Gaga in Indonesia, especially in Jakarta.

They firmly opposed Lady Gaga using the word "refuse" to show their disagreement, since, according to them, Lady Gaga is one a western singer who brings the faith of Satan, which would drive to moral damage. This sentence labeled the FPI as the extremist group of Islam who will warn and even ban this kind of event. The FPI would strongly monitor western or eastern singers who might cause moral damage. This could be due to their clothes, dance, and music, for example. Lady Gaga is one of the singers who would spread pornography through her songs and lyrics. The power of the verbal process by quoting Habib Salim is more powerful than only delivering the FPI's ideology without any trusted sources to construct its image. The promoter had directly replied this case in an article:

Big Daddy president director Michael Rusli said that the company remined optimistic on the concert. "This week we will process the permit with the Jakarta Police and the National Police. What has become the issue here is that many have misunderstood the performer and the show. We will explain this during the permit-making process." (JP.4/Clause No. 32-34)

Again, these sentences are verbal processes which reveal the clarification from the promoter. They stated that what the FPI mentioned about Gaga was only misunderstood; they will stand to explain it to the police. This part tended to be worth for the journalist to keep the balance with the reader's understanding about the real situation. Moreover, it was supported by the dissappoinment of Lady Gaga's fans: "Some of Lady Gaga's fans, known as Little Monsters, voiced dissappoinment with Jakarta Police's decision" (JP.4/ Clause No. 45).

This sentence is a verbal process with the word "voiced" as the verb, rather than the ordinary "said." The journalist intentionally used it to express their hard complaint about the Jakarta Police. This strategy is needed to support the promoter's state. Many local fans also wished her to come.

\section{Image Construction of the Islamic Defenders Front in the Case of Ahok as Jakarta's Governor}

This issue is the most recent; the disputable case of the inauguration of Ahok as the next governor of Jakarta, replacing the previous governor Jokowi. The author found 51 clauses.

Figure 3 highlights that the journalist used the material process to deliver the news to the audiences, so that the readers could visualize and imagine the chronological order clearly. A happening that somebody carries out can be labeled as the material process. The processes which constructed the image of this issue are "arrived," "brought," "inaugurated," and "disrupting:"

Around 1,000 members, who wore white uniforms and brought banners reading "Hey Ahok, shut your mouth!", arrived at the building on Jl. Kebon Sirih in Central Jakarta at 11 a.m., after starting their march from FPI headquarters on J1. KS Tubun, 
Petamburan in West Jakarta at 9 a.m. (JP.5/Clause No. 2 and 3)

This news began with the narration that the FPI fulfilled their promise to lead the demonstration against Ahok's establishment. The journalist described the FPI's members as wearing the white. The next clause, which was still explanation of the head noun, was strengthening their less politeness. The sentence "Hey Ahok, shut your mouth" was one of the hate speeches that they used to offer when confessing their anger towards issues in Indonesia. They arrived after a long march: "Members of the hard-line Islam Defenders Front (FPI) 'inaugurated' their choice for Jakarta governor, Fahrurozzi, during their latest protest outside the Jakarta City Council (DPRD) building against the governorship of Basuki 'Ahok' Tjahaja Purnama" (JP.6/Clause No. 1).

The ceremony of inauguration of Fahrurozi as the right governor of Jakarta was one of the creative ways to gain the citizens' attention during their protest. Hence, one of the functions of doing such demonstration was to lead people's opinion about any issues. Thus, they stood as the rival of Jakarta's government who had appointed Ahok as the governor. The FPI was still trying to meet their aim to block Ahok. According to the FPI, Ahok did not deserve to lead Jakarta because he was not only Christian and Chinese, but also arrogant and ignorant. This part is another hate speech of the FPI confessing their anger towards their disagreement: "After the quick 'inauguration ceremony,' Fahrurozzi and his supporters marched toward the nearby City Hall, once again disrupting traffic with their protest" (JP.6/Clause No. 18).

The sentence above indicates the journalist used the process "marched" to show that they walked with anger, not only in an ordinary "walk." The image the next process "disrupting" supported means that their demonstration, after the establishment of the governor, did not solve the problem. Their march nearby the City Hall did not please people. Moreover, the FPI increased

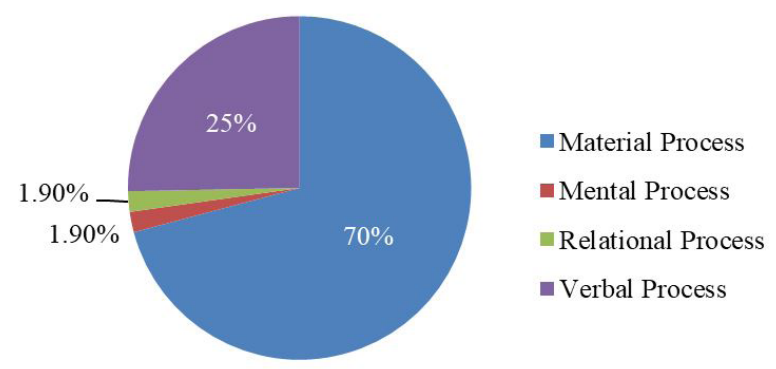

Figure 3. Percentage of type of process in the case of Ahok as Jakarta's governor people's hardship by disrupting the traffic of Jakarta, the most crowded city in Indonesia with jamming as the endless problems.

In the case of Ahok, the journalist constructed the image of the FPI as the protester who did the rally at the City Council. The process the journalist used to show the FPI's protest are "march," "demonstrating," and "disrupting." According to the FPI, Ahok did not deserve to lead Jakarta; he was not only Christian and Chinese, but also arrogant and ignorant. On that day the FPI was not only doing the rally at the city council, but also disrupting and worsening the traffic jam in Jakarta.

\section{CONCLUSION}

In constructing the image of the FPI, the Jakarta Post used the material process as the dominant process in all the articles. The material process represents 51\% (47 clauses) in the case of Ahmadiyah, 41\% (27 clauses) in the case of the arrival of Lady Gaga, and 70\% (36 clauses) in the case of Ahok as Jakarta's governor. The material processes the author found in the Jakarta Post indicate the newspaper constructed the FPI as one of the hardline organizations of Islam that obviously reacts rudely towards many issues in Indonesia, especially issues about moral and Islam. The journalist used the material process to describe the FPI's activities in the above-mentioned three chosen issues.

Beside the material process (i.e., "burned," "attacked," "burned," "drive away," and "vandalized") to construct a negative perception of the FPI, the journalist also used the verbal process to strengthen this image. Also, the journalist quoted some testimonies from the victims, polices, and also the direct speech of the FPI itself. As a result, the readers are easily "injected" with these six articles while thinking about the FPI.

It is also relevant to discuss about the implications of Halliday's SFL in pedagogy (Wachidah, 2010). By using SFL, the teachers are facilitated at least in three sides of language learning: The goal of teaching, the material, and the method. SFL triggers the teachers to apply the passages by its function, seeing the passages not only by the meaning of the words, but also by its function. Regarding the teaching material, SFL suggests the teachers to use texts which contain daily life events and substances, such as news, manual, recount, and descriptive. These materials can be thought by the traditional or modern method. Accordingly, this analysis can be used as an example of passage comprehension strategy and critical reading. 


\section{ACKNOWLEDGEMENT}

The author would like to acknowledge and express her greatest gratitude to the Indonesia Endowment Fund for Education (LPDP) for the support of her research expansion. The author would also like to thank Mrs. Hasnini Hasra, M. Hum for her assistance, advice, and support during this research.

\section{REFERENCES}

Campbell, R. (2005). Media and culture: An introduction of mass communication. Boston: Bedford/St.Martin's.

Campbell, R. (2012). Media and culture: An introduction of mass communication (8th edition). Boston: Bedford/ St.Martin's.

Halliday, M. A. K., \& Matthiessen, C. (2004). Introduction to functional grammar (3rd ed.). London: Routledge. Retrieved from https://www.functionalmedicine.org/ files/library/Intro_Functional_Medicine.pdf

Haratyan, F. (2011). Halliday's SFL and social meaning. In Proceedings of the 2nd International Conference on Humanities, Historical and Social Sciences IPEDR (vol.17).
Pausaker, H. (2012). Playboy, the Islamic Defenders Front and the law: Enforcing Islamic norms in postSoeharto Indonesia? Australian Journal of Asian Law.

Ratna, N. K. (2004). Teori, Metode, dan Teknik Penelitian Sastra. Yogyakarta: Pustaka Pelajar.

Wachidah, S. (2010). Linguistik Fungsional Sistemik (Systemic Functional Linguistics) untuk Pendidikan dan Penelitian Bahasa. Konferensi Linguistik Tahunan Atma Jaya, 8, 265-269.

Woodward, M., Yahya, M., Rohmaniyah, I., Coleman, D. M., Amin, A., \& Lundry, C. (2012). Hate speech and the Indonesian Islamic Defenders Front. Tempe, AZ: Arizona State University, Center for Strategic Communication. Retrieved from http://csc.asu.edu/ wp-content/uploads/pdf/csc1203-fpi-hate-speech.pdf

Young, L., \& Fitzgerald, B. (2006). The power of language: How discourse influences society. London: Equinox Publishing. 